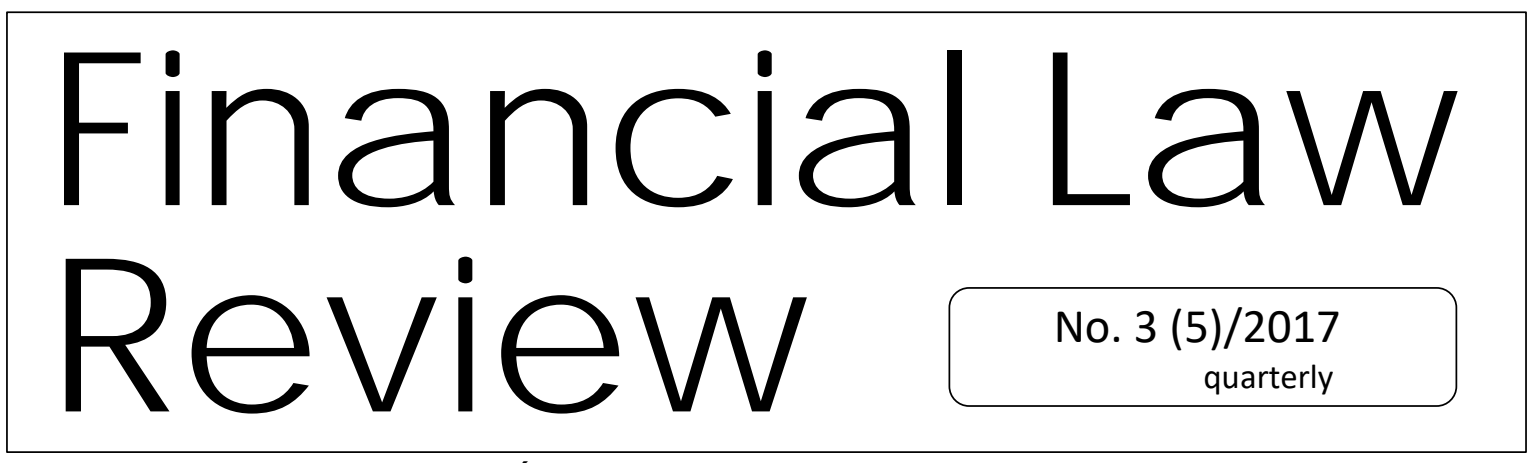

UNIVERSITY OF GDAŃSK • FACULTY OF LAW AND ADMINISTRATION http://www.ejoumals.eu • http://cza so pisma.bg.ug.edu.pl

\title{
INTERPRETATION OF THE TAX LAW IN FRANCE. SELECTED PROBLEMS ${ }^{1}$
}

Mariola Lemonnier*

\section{Abstract}

The autonomy of the tax law in French law was not immediately doctrinal project. The first step was the use of autonomous interpretation by the judges of the Conseil d'Etat. The article presents the interpretation and doctrinal conflicts in French tax law. The experience gained through the practice of the tax law in France can be a contribution to the discussion on the same problem in Polish law.

\footnotetext{
${ }^{1}$ The article is a reprint of the article originally published in Prawo Finansowe wobec wyzwan XXI wieku. The Financial Law Towards Challenges of the XXI Century, J. Gliniecka, A. Drywa, E. Juchniewicz, T. Sowiński (ed.), CeDeWu Warszawa 2015

* Dr hab. Mariola Lemonnier, prof. UWM, kierownik Katedry Prawa Finansowego, Wydział Prawa i Administracji, Uniwersytet Warmińsko-Mazurski w Olsztynie
} 
In the French law interpretation is understood rather as an activity of interpreting by the judge. It does not focus on legal methods or techniques, but rather on the judge's freedom and the limits of this freedom. The person interpreting the law does not make a source of the law for himself ${ }^{2}$.

Finally, law doctrine attempted to organise various concepts of case-law interpretation distinguished between interpretation techniques and methods of interpretation. The former indicate the outcome of the interpretation formalise the intellectual process, the way to reach the outcome. On the other hand, interpretation methods sensu stricto are the final basis for the solution adopted in a ruling and are not imposed on the judge in an absolute manner.

There have been certain studies on differences between interpretation techniques and methods. However, the practice of law has actually eliminated these differences and the language of law in France does not distinguish between these two concepts ${ }^{3}$. Representatives of the French law doctrine think about this approach to interpretation since it has gradually become an ambiguous term for many representatives of the doctrine or the practice. It was the term which denoted both the process and the outcome of the process, both the activity and its effect ${ }^{4}$. As highlighted by representatives of the doctrine, interpretation denotes actions through which a certain meaning is assigned to objects (objet), utterances (énoncé), and results of these actions (produit de l'opération) ${ }^{5}$. One of the problems stemming from the above approach is the issue of legal principles: they are not included in provisions which reflect the outcome of interpretation. However, these rules are at the same time the object of interpretation, which forms a part of the judge's inference making process and influences the meaning of the interpreted texts in a constructive way.

Interpretation models used in France have different origins and different outcomes.

In the exegetical school, created by J. Bodin and Th. Hobbes, the only source of the law is a written act, and the judge is "the mouth of the law" ${ }^{\text {" This was to }}$

${ }^{2}$ F. Geny, Méthode d’ interpretation et sources en droit positif - Essai critique, Paris 1899, p. 25.

${ }^{3}$ D. Allan, S. Rials, Dictionnaire de la culture juridique, PUF 2003, p. 844.

${ }^{4}$ S. Sur, Interpretation en droit international public, (in) P. Amselek, Interpretation et Droit, Bruylant, Bruxelles 1995.

${ }^{5}$ M. Troper, Interpretation, (in) P. Amselek, op. cit., p. 843.

${ }^{6}$ H. Rabault, Granice wykładni sędziowskiej, Fundacja Promocji Prawa Europejskiego Instytut Wymiaru Sprawiedliwości, Wyd. Naukowe Scholar 1997, p. 5. 
prevent law abuse, typical of the Ancien Regime. The administration of justice is the fulfilment of the legislator's will and the interpretation is the judge's right $^{7}$. Interpretation is made within the limits of the written law. Since the legislator's will was to be sought at all costs, and despite the risks, interpretation was to be strict, literal, which consequently diminished its importance. The exegetical approach assumes the coherence of the legal order, both within the system itself and in its application. Exegesis leads to using methodology based on deduction; formal logic becomes an instrument for interpretation ${ }^{8}$.

The second approach, known as free scientific research, postulated that during the process of interpretation the judge should take into account not only the written law, but also the theory of law, moral principles or social considerations. This approach negates the principles of unity and coherence of the legal order. The school of free law criticises the monopoly of the written law as a source of law as well as negates the equation "law equals a written act" . Lawyers are guarantors of the legal order, and the judge may adapt a written law, by correcting it or even deviating from it, but always in compliance with the law. Professor F. Geny, one of the most influential French theorists and the creator of the free scientific research movement, put forward an extended theory of free hermeneutics as a theory of free scientific research. Within this theory he pointed to the contribution of interpretation to the development of jurisprudence and rejected the cult of the written and codified law.

He claims that natural, economic, social and other considerations are nonnormative sources of the $\mathrm{law}^{10}$. The free scientific research movement highlights the existence of gaps and obscurities of written laws. It is for this reason that these non-formal sources of the law should be taken into account when applying written laws.

Under the influence of the German doctrine, Geny advocates the trend of searching for the meaning of the law ${ }^{11}$, but also adheres to the traditional

\footnotetext{
${ }^{7}$ Idem, p. 10.

${ }^{8}$ Idem, p. 15.

${ }^{9}$ J. Carbonnier, Flexible droit. Pour une sociologie du droit sans vigeur, Paris, 1992, p. $20 \mathrm{ff}$.

${ }^{10} \mathrm{H}$. Rabault, op. cit., p. 16, it is worth highlighting that there was an approach within the theory of law which attributed importance to definitions and concepts used in the German law, i.e. Begriffsjurisprudenz. In this approach formal logic is the basic methodological instrument for interpretation.

${ }^{11}$ F. Geny, op. cit., p. 267.
} 
concept of a text as an expression of the will of its creator. He attributes more importance to interpretation made with the use of methods typical of scientific research ${ }^{12}$. Nonetheless, twenty-five years later the same author will write that tax issues should be excluded from the freedom of interpretation as they are the exclusive competence of the law-maker. Such an approach to the tax law indicates both its special nature and at the same time difficulties inherent in its interpretation.

In the exegetical school strict interpretation of the tax law was supported by the legal maxim 'in dubio contra fiscum', or - in the words of Professor Geny - a reminiscence engrained in the social memory which juxtaposed the postrevolutionary times with the previous form of government, i.e. the Ancien Regime. The conditions of strict interpretation may also be viewed from this perspective. All consideration in the tax law gained a different dimension when the theory of the autonomy of the tax law first appeared.

The French theory of interpretation changed considerably under the influence of Hans Kelsen's theses presented in France in 1962 by Charles Eisenmann, who on ten pages elaborated that interpretation cannot be solely an act of knowledge, but must also be an act of the judge's will ${ }^{13}$.

The tax law history has undergone many changes in the context of the theory of interpretation. At the beginning solutions were imposed by the general theory of interpretation dominant in a given period, without developing any independent doctrine. At the end, however, the tax law developed its own theory of interpretation, autonomous and isolated in the French legal literature. The autonomy of the tax law and the theory of legal realism in the tax law were so important that when the theory of the autonomy was introduced, it resulted in the automatic breakaway from the general theory of legal interpretation and the exegetical school of interpretation. The autonomy theory gave the tax law a new place in the legal system and led to the application of a new interpretation theory. The author of the autonomy theory, Professor Trotabas, emphasised that the tax judge has a special power of creation, similarly as was the case with the administrative law.

The meeting of two authors of opposing theories in the French law (Professor Geny and Professor Trotabas, and afterwards Professor Cozian) had to trigger a dispute on the doctrine. The interpretation of the tax law depends on the

\footnotetext{
${ }^{12}$ J. Lamarque, Droit fiscal, Litec 1994/95.

${ }^{13}$ Hans Kelsen, Théorie pure du droit, translated by Ch. Eisenmann, Dalloz, 1992, p. 453 ff.
} 
place the tax law has among other branches of the law. The autonomy of the tax law dominated the theory of its interpretation for fifty years. Not surprisingly, then, the words written in 1980 by Professor M. Cozian, then a young professor of the private law, who opposed the hegemony of the autonomy theory, marked a breakthrough in the interpretation theory and the legal realism theory. Realism was not a unified school, but rather a type of a research movement, whose French representatives reached surprising conclusions, especially as regards the position of the judge. In 1975, M. Troper wrote that interpretation included not a single objective element or a scientific one that might bind the interpreting person. It is an act of the judge's will. Consequently, the true law maker is not the Parliament but the person making the interpretation, i.e. the judge. In the times of Napoleon and Montesquieu, judges were only the mouth of the law and their main task was to enforce the law. In the 20th century they suddenly became law-makers (in the view of some extreme theories).

Suddenly, the field of the tax law became the intellectual battlefield. Lack of autonomy of the tax law was coherent with the idea of interpretation as an act of knowledge and discovering the law. Consequently, the strict interpretation was to discover the only true content of a provision.

On the other hand, the autonomy of the tax law would give the tax judge the role of the law-maker, on the basis of the realism theory, which would result not in an act of the judge's knowledge, but rather of the judge's will. From this perspective, criticism of the autonomy theory was justified. At the same time works were also published which separated the two issues: autonomy and interpretation. There were attempts to diminish the importance of the interconnections between these two issues, in which it was pointed out that autonomy is a purely technical question ${ }^{14}$. Each theory contributed to the theory of interpretation. The classical theory provided instruments allowing lawyers to operate freely within the technical and operational whole so as to arrive at a useful interpretation. The theory of autonomous interpretation pointed to the lack of authoritativeness and certainty of the interpreting person.

\section{The origins of the theory of the autonomy of the tax law in the French law}

\footnotetext{
${ }^{14}$ J.-P. Maublanc, L'interprétation de la loi fiscale par le juge de l’impôt, Bordeaux I, 1984, p. 14.
} 
The beginning of the autonomous approach to the tax law and breaking away from the exegesis of tax regulations in France is dated at 1926. This thesis was put forward by Professor Louis Trotabas in cases conducted before the French Council of State (French: Conseil d'Etat, "Council"). This presentation at the same time broke away from the general theory of interpretation and the exegesis of the tax law. Tax judges were granted a certain authority to make law, even though this authority remained underspecified; disputes on this matter as well as research studies have been carried out to this day.

It is worth emphasising that the judge's "interpretation" is an intermediary stage between the normative statement and the statement directed to the addressee of the ruling. The word "interpretation" derives from the Latin word for "intermediary, translator". Today it is understood much more broadly. Interpretation of the law reveals elements included in provisions; it is a reconstruction placed somewhere in between the process of creating law and autonomous application of provisions.

It is worth noting that in France the court jurisdiction depends on the type of the tax, which is not the case in the Polish law. Direct taxes are the competence of administrative courts, in which the tax application and interpretation are dominated by the autonomy doctrine. Indirect taxes, excluding the turnover tax (which is subject to administrative courts), remain the competence of common courts, imbued with the spirit of the private law and inspired by private law concepts. Therefore, the discussion on the autonomy of the tax law and autonomous interpretation of its provisions has more serious consequences than in the legal systems of other EU Member States, including the Polish law. The history and path of the autonomy of the tax law in France may also be perceived as an attempt to unify the subject matter jurisdictions in tax cases.

The doctrine of the French tax law uses the term "tax judge" (for judges deciding in tax cases) to avoid divisions in tax cases and put even more emphasis on the need to establish the "common denominator".

The key argument for the autonomy approach in the tax law was the need to prevent tax evasion (l'evasion fiscale) and tax fraud (fraude). This applied not only to the judge's interpretation, but also to the interpretation by tax administration or tax legislation. 
The objective of the autonomy of the tax law ${ }^{15}$, and more specifically its version proposed in commentaries on the law, was to protect the tax office. It was criticised for its automaticity and the potential lack of impartiality on the part of the judges. In 1954 Professor R. Drago wrote that the interests of the tax office dominated over legal events in the private law and even in the administrative law.

Since the beginning of the 19th century, the French tax law was taught by civil law specialists and their lecturing methods and interpretation always were close to the biblical exegesis. In 1902, A. Wahl wrote that the civil law was precise, it was a branch of law dominating over the tax law and not subject to it $^{16}$. The same author highlighted that "I don't know civil law, I only teach the Napoleon's Code of 1804 "17. Such cult of the civil code paved the way for opinions on the absolutism of the civil code. This attitude to the code allowed neither for considerations of philosophical or ideological aspects of the tax law nor for considerations of social issues in the tax law.

The autonomy of a branch of law is not specific to the tax law. As mentioned earlier, the issue of the autonomy came to the foreground due to tax evasion and tax fraud.

The aim of the Professor from Aix, who authored the claims of the autonomy of the tax law in France, was to elevate the tax law. Interestingly enough, after a fiftyyear dispute, even the fiercest opponents of the Dean Trotabas used the same argument to support a claim to the contrary (as witnessed by the example of Professor Cozian).

The debate on the autonomy of the law has not been a purely theoretical matter. This has not been only a debate between the doctrines of the private law and the public law, or between the tax law and the administrative law. Even more so it has not been a terminological debate ${ }^{18}$. In a short time the

\footnotetext{
${ }^{15}$ The question of the autonomy of the tax law in the Polish literature was discussed in: A. Gomułowicz, Zwiazki prawa cywilnego z prawem podatkowym, P. Pod. 1996, v. 11 p. 3, A. Gomułowicz, J. Małecki, Podatki i prawo podatkowe, Poznań 2000, p.101 ff., B.Brzeziński, Prawo podatkowe, Torun 1999, Wstęp do nauki prawa podatkowego, Toruń 2001, J.Głuchowski (in) Finanse publiczne i prawo finansowe, eds. C. Kosikowski, E. Ruśkowski, W. Nykiel, Autonomia prawa podatkowego (wybrane zagadnienia) (in) Konstytucja, ustrój, system finansowania państwa, księga pamiątkowa ku czci prof. N. Gajl, Warszawa 1999, p. 404, M. Zirk-Sadowski, Problem autonomii prawa podatkowego w orzecznictwie NSA, POP 2004, v. 2 p. 114.

${ }^{16}$ A. Wahl, Traité de droit fiscal - Introduction, T.I LGDJ 1902, p. XV.

${ }^{17}$ J.-L. Halperin, D. Alland, S. Raili, Dictionnaire de la culture juridique, PUF 2003, p. 684.

${ }^{18}$ M. Collet, Droit fiscal, PUF 2007, par. $162 \mathrm{ff}$.
} 
debate extended to include the interpretation of the tax law in relation to other branches of the law within the French law system.

The autonomy and realism of the tax law dominated between 1920 and 1980. The Dean from Aix, Professor Trotabas, created and developed the theory of autonomy and realism of the tax law. He believed that the autonomy did not equal the isolation of the tax law, and even more so it was not tantamount to the ignorance of the law and its systematic violation. In most cases administrative judges apply the theory of realism in the tax law when they borrow concepts from other branches of the law, but they add "from the tax law perspective". Nonetheless in France realism was more of a justification of the doctrine than of the case law.

In 1921, before the autonomy theory was formulated, a commissioner in the Council of State (Conseil d'Etat), Corneille, said about the tax law that it was the kind of law which "concerns the taxation object and calculates the tax in the place where this object is and in the condition it is in". What the judge Corneille wanted to highlight in 1921 was a shy attempt at classifying taxation with respect to other branches of the law ${ }^{19}$. A judge who decided to move away from legal qualifications from other branches of the law was judged by the doctrine, which almost automatically pointed to the realism of the tax law and voiced criticism.

\section{Controversies around autonomy}

Before the legal measures to fight tax fraud (fraude a la loi fiscale) were introduced in the French tax case law, both administrative (1981) and common (1987), the theory of autonomy and realism was an alibi for issuing prejudiced interpretations of the tax law. This period in the case law had an impact on the understanding of the theory of realism as protection of the tax office's interests ${ }^{20}$.

The author of the theory, Professor Trotabas, encouraged the Council of State to move the issues of coherence between the tax law and other branches of the law into the background. This move, on the one hand, led the judge to look on the fundamentals of the tax law as if the search for coherence with other

\footnotetext{
${ }^{19}$ Ruling issued only in 21.03.1930.

${ }^{20}$ In the administrative case law this trend was clearly noticeable, this was even more pronounced when collections of case law, "Tables de Recueil Lebon", started to include (since 1960) a column on the tax realism. The column on the autonomy of the tax law appeared only exceptionally.
} 
branches of the law was unnecessary. It was during that period that the Council issued rulings which granted (under the tax law) legal personality to a civil law partnership, even though the civil law did not change in this respect.

The main opponent of the Dean Trotabas's theory was Professor Maurice Cozian, who classified some of justifications of rulings as 'a cream cake for the tax office' (tarte a la creme pour le fisc), accusing them of ignorance or being an easy camouflage for ignorance ${ }^{21}$.

Since 1980 Professor Cozian's article has dominated the tax law doctrine. Even the judges in the Council themselves asked the question - what was left of the autonomy of the case law. They also concluded that the theory of legal realism was a "museum artefact", a concept forgotten by everyone.

There was a noticeable deviation from the theory of autonomy among representatives of the public law doctrine, who were later joined by representatives of the private law.

In spite of this, as late as in 1979, Professor Cozian in his work Précis de fiscalité des entreprises listed autonomy and realism as features of the tax law!

Representatives of the public law mentioned the theory authored by the Dean Trotabas only when they wanted to criticise it. Professor Trotabas's public response was that the theory of autonomy was artificial and addressed to the wrong audience by a young professor that he was in the 1920s. The failure of the theory was also due to hopeless cases in which he defended the Ministry of Finance before the Council of State. The Professor's confession provoked even more criticism as it lacked sophistication. Professor Trotabas remained faithful to his theory, but more on account of his sentiment and memories of a young researcher rather than because of his true beliefs.

In the twentieth century agreement between taxation and the law came to an end. However, the news on the death of the autonomy of the tax law was premature; analysts of the tax case law pointed out that the autonomy was doing quite well.

${ }^{21}$ M. Cozian, Droit fiscal 1980, No 41, p. 1054, JCP 1980, I, 3005. 
Restrictions or setting limits on a given branch of the law mean also taking responsibility for its marginalisation. However, the force with which Professor Cozian launched an attack on the autonomy of the tax law fifty years later was justified by the objective of giving a higher position to the tax law. The Professor wrote that a fifty-year separation of the tax law was successful, maybe even a little too successful since it led to the isolation of the tax law in relation to other branches of the law. Still, this did not enhance the profile of the tax law in society. And most likely this is what worried French theorists most... 